\title{
Determination of Critical Micel Concentration of PEG-10 Tallow Propane Amine: Effects of Salt and pH
}

\author{
Nese Ataci*, Ayfer Sarac \\ Department of Chemistry, Faculty of Science \& Art, Yildiz Technical University, \\ Istanbul, Turkey \\ Email: *atacin@yahoo.com
}

Received November 8, 2013; revised December 15, 2013; accepted December 29, 2013

Copyright (C) 2014 Nese Ataci, Ayfer Sarac. This is an open access article distributed under the Creative Commons Attribution License, which permits unrestricted use, distribution, and reproduction in any medium, provided the original work is properly cited. In accordance of the Creative Commons Attribution License all Copyrights @ 2014 are reserved for SCIRP and the owner of the intellectual property Nese Ataci, Ayfer Sarac. All Copyright (C) 2014 are guarded by law and by SCIRP as a guardian.

\section{ABSTRACT}

Most applications of surfactants depend on formation and characteristics of micelle. In this study we measured critical micelle concentration (CMC) of cationic surfactant $N$, N', N'-polyethylene (10)-N tallow-1, 3-di amine propane (PEG-10 tallow) in aqua solution by using electrical conductivity and surface tension methods. The CMC value of PEG-10 tallow with two different methods was found very close to $1.40 \times 10^{-3} \mathrm{M}$ with electrical conductivity, and $1.41 \times 10^{-3} \mathrm{M}$ with surface tension. It also investigated the effect of inorganic salt (NaCl) and pH on micellization of cationic surfactant PEG-10 tallow. With increasing addition of NaCl, formation of micelle structure resulted in a higher CMC. However, at low salt concentrations smaller CMC value was observed comparing the critical micelle concentration of individual PEG-10 tallow. When it comes to the effect of changing $\mathrm{pH}$ in CMC of the PEG-10 tallow, it was clearly found that micelle formation or CMC of surfactant was independent on alkaline pH (between 6 and 10), but it was dependent on acidic pH (below 5).

\section{KEYWORDS}

\section{Cationic Surfactant; PEG Groups; CMC; Surface Tension and Electrical Conductivity; NaCl; pH}

\section{Introduction}

Surfactants or surface active agents have a wide range of applications in industries, agriculture, textile, detergent, food, cosmetics and the drug or pharmaceutical [1,2]. Surfactants consist of a long non-polar or hydrophobic such as single or double bonds, saturated and unsaturated hydrocarbon tail and a polar or hydrophilic with ionic, nonionic or zwitterion head groups [3].

Cationic surfactants are one of the major types of the ionic surface active agents with positively charged hydrophilic head group and a hydrophobic tail group. Antibacterial, antistatic, corrosion inhibitory, dispersants, emulsifying, wetting and solubilizing agent's properties of cationic surfactants are well known [1,4,5]. However, in last decade, the cationic surfactants have attracted immense interest in the development of methods for separation, purification and extraction of DNA. The cationic surfactants have also been tested for gene delivery and gene

"Corresponding author. transfection which have involved in current clinical trials based on gene therapy [6,7]. Many cationic surfactants also showed interesting properties, for example; cetylpyridinium chloride was a single-chain cationic surfactant with well-known antibacterial properties and in the presence of cetylpyridinium chloride strong complexes formed between nucleic acids and cationic liposoms for the transfection of plasmid into the cell. Cetyltrimetyl ammonium bromide (CTAB) was used to control the rate of DNA renaturation and to precipitate selectively plasmid DNA from RNA proteins and endotoxins [8,9]. Doublechain cationic surfactant dimethyldialkylammonium bromide has shown immune adjuvant properties. A cationic gemini surfactant dodecyltrimetylammonium bromide (DTABr), and tetradecyltrimetylammonium bromide (TT$\mathrm{ABr}$ ) have been also used for determining interaction between surfactant and DNA $[8,10,11]$.

Micelle formations are important in clinical or pharmaceutical applications specifically in physiological con- 
ditions; since they directly affect DNA/cationic surfactant interaction driven by both electrostatic attraction and hydrophobic effect $[7,12]$.

The cationic surfactant and other types of surface active agents form micellar structure at or above concentration are known as the critical micelle concentrations (CMC) in solution. The assembly of the cationic surfactants into micelle can be explained by the relative interactions between the hydrophilic and hydrophobic segments with one another and the surrounding medium $[12,13]$. Therefore, micellar properties of the surfactants in solution have affected external factors such as $\mathrm{pH}$, temperature, salt, pressure and additives $[4,12,14]$. CMC can be determined by many different techniques including surface tension, turbidity, self-diffusion, conductivity, osmotic pressure, solubilization, surfactant selective electrodes and fluorescence [3].

In our previous paper [15], it was found that N, N', N'Polyethylene (10)-N tallow-1,3 di amine propane (PEG10 tallow) cationic surfactant is usable for the selective precipitation of plasmid DNA directly from alkaline lysate. Cationic PEG-10 tallow has long-chain $\left(\mathrm{C}_{12}-\mathrm{C}_{18}\right)$ tertiary amines combined with 10 moles poly (oxyethylene) (POE) [15,16]. However, no reports appear available on the CMC of PEG-10 tallow under different conditions. The aim of this work is to investigate the critical micelle concentration of the cationic surfactant PEG-10 tallow in aqueous solution, in different salt concentrations and also in $\mathrm{pH}$ values. The CMC of PEG-10 tallow was determined in all conditions by surface tension and electrical conductivity methods.

\section{Experimental}

\subsection{Materials}

Cationic surfactant N, N', N'-Polyethylene (10)-N tallow-1,3 di amine propane (PEG-10 tallow) was purchased from Sigma-Aldrich and used without purification. Sodium chloride, sodium hydroxide and hydrochloric acid were of analytical grade, and also using without further purification. Deionized Milli Q water was used in all experiments. Stock solution of surfactant, salt, acid and base were prepared with deionized water.

\subsection{Characterization of PEG-10 Tallow Propan Amine}

The weight average molecular weight $\left(M_{w}\right)$ of PEG-10 tallow which was given chemical structure in Figure 1 was determined by using MALDI-TOF MASS and was found $722 \mathrm{~g} \cdot \mathrm{mol}^{-1}$. MALDI-TOF MASS spectrum was acquired in linear modes with average of 50 shots on a BrukerDaltonicMicroflex mass equipped with a nitrogen UV-Laser operating at $337 \mathrm{~nm}$ without using matrix.

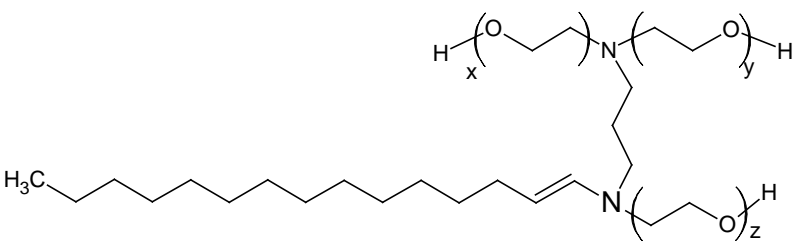

Figure 1. Structure of PEG-10 tallow $(x+y+z=10)$ [15].

\subsection{Determination of CMC of Surfactant}

\subsubsection{Surface Tension Method}

Surface tension measurements were done by applying du Nouy ring method using a KSV Sigma 701 model tensiometer and platinum ring at room temperature $\left(25^{\circ} \mathrm{C}\right)$. Stock solution of $5 \%(\mathrm{v} / \mathrm{v})$ of PEG-10 tallow in aqua was prepared in $1 \mathrm{~L}$ volumetric flask. First of all, the surface tension of pure water in a glass vessel was noted. The surface tensions were measured by a dilution method in which a $5 \%(\mathrm{v} / \mathrm{v})$ of PEG-10 tallow stock solution was gradually diluted by deionized water. After each dilution the solution was stirred for $30 \mathrm{~s}$, and then left for $2 \mathrm{~min}$ before reading the surface tension value. All surface tension measurements were done at least three times or up to obtaining repeated value. The CMC values in different experimental conditions such as $\mathrm{pH}$ and salt concentrations were determined by plotting surface tension versus concentrations of surfactant.

\subsubsection{Conductivity Method}

Conductivity measurements were done using a WTW model Con 340 i conductometer having standard conductivity measuring cell was equipped with graphite (model Tetra Com 325/C with temperature sensor, cell constant $=0.475 \mathrm{~cm}^{-1} \pm 1.5 \%$ ). $0.01 \mathrm{~mol} \cdot \mathrm{L}^{-1} \mathrm{KCl}$ was used as calibration standard for conductivity cell. Conductance was measured by a dilution method in which a $5 \%(\mathrm{v} / \mathrm{v})$ of PEG-10 tallow stock solution was gradually diluted by deionized water. After each dilution the solution was stirred for $30 \mathrm{~s}$, and then left for 1 min before reading the conductivity value. All conductivity measurements were done at least three times or up to obtaining repeated value. The CMC values in different experimental conditions such as $\mathrm{pH}$ and salt were determined by plotting conductance versus concentrations of surfactant.

\section{Results and Discussion}

\subsection{CMC of the Cationic Surfactant}

The micelle forming concentration of PEG-10 tallow cationic surfactant was followed by measuring conductivity and surface tension in aqueous medium. An example of conductivity measurements was shown in Figure 2, where the conductivity $(X)$ obtained for the cationic surfactant solution is plotted as a function of the cationic 


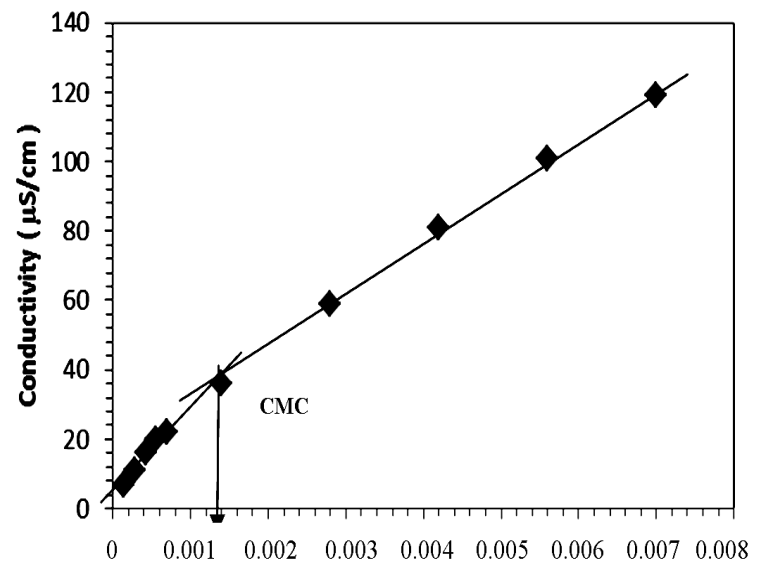

Figure 2. Conductivity $(\chi)$ of aqueous solution as a function of [PEG-10 tallow] at $25^{\circ} \mathrm{C}$.

surfactant concentration at $25^{\circ} \mathrm{C}$. Conductivity increases almost linearly with the increase PEG-10 tallow concentration, and the slope changes steeply at certain concentration in the Figure 2. This steep change of the slope in $X$ vs concentration plot demonstrates that the molecular micelles starts to form at the concentration of $1.40 \times 10^{-3}$ M. This point is confirmed by surface tension method in Figure 3 where a break point or slope change is also seen in good agreement with Figure 2. The typical curve expected for such single tail cationic surfactant systems was obtained in the given figures.CMC was overlap for surface tension and conductivity methods. The addition of cationic surfactant in water the surface tension $(\gamma)$ decreases up to the critical micelle concentration of 1.41 $\times 10^{-3} \mathrm{M}$, and further addition of surfactant did not affect the surface tension as expected very seriously [16].

\subsection{The Salt Effect on the CMC of the Cationic Surfactant}

The salt effects on CMC of PEG-10 tallow were investigated by two different methods as shown in Figure 4 and Figure 5. Surface tension and conductivity measurements were done by using different $\mathrm{NaCl}$ concentrations of $0.5 \times 10^{-3} \mathrm{~mol} \cdot \mathrm{L}^{-1}, 0.8 \times 10^{-3} \mathrm{~mol} \cdot \mathrm{L}^{-1}, 1 \times 10^{-3} \mathrm{~mol}$ $\cdot \mathrm{L}^{-1}$, and $2 \times 10^{-3} \mathrm{~mol} \cdot \mathrm{L}^{-1}$. The values of CMC obtained in different $\mathrm{NaCl}$ concentrations are quite similar to each other. CMC graphs were given in Figure 4(a), and obtained CMC values were given in Table 1. Generally the salt addition decreases the CMC of ionic surfactant. The added salts screen electrostatic repulsions between head groups and make the surfactants effectively more hydrophobic. The increased hydrophobicity interaction among the surfactants molecules cause them to aggregate at lower CMC. In another words, more micelles were formed with the addition of salt $[3,14,17]$.

Figures 4 and 5 showed that adding very small amount of $\mathrm{NaCl}\left(0.5 \times 10^{-3} \mathrm{~mol} \cdot \mathrm{L}^{-1}\right.$ and $\left.0.8 \times 10^{-3} \mathrm{~mol} \cdot \mathrm{L}^{-1}\right)$

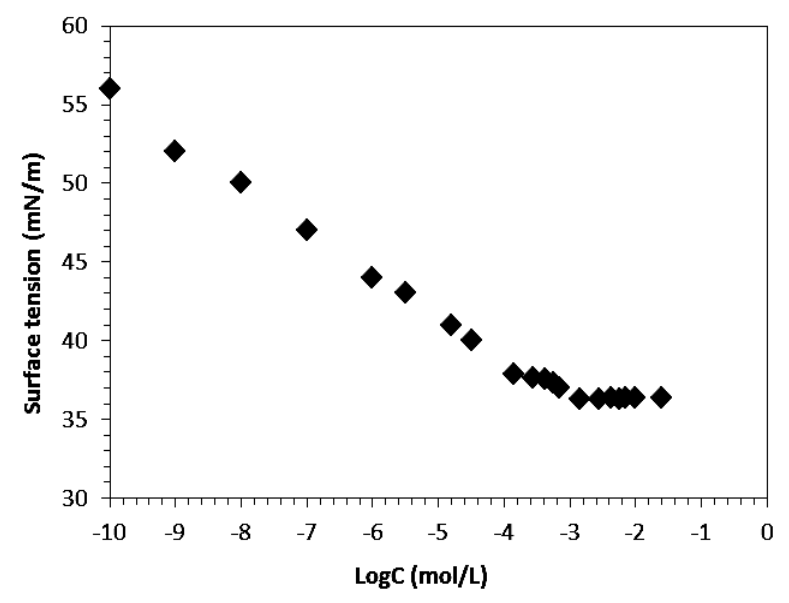

(a)

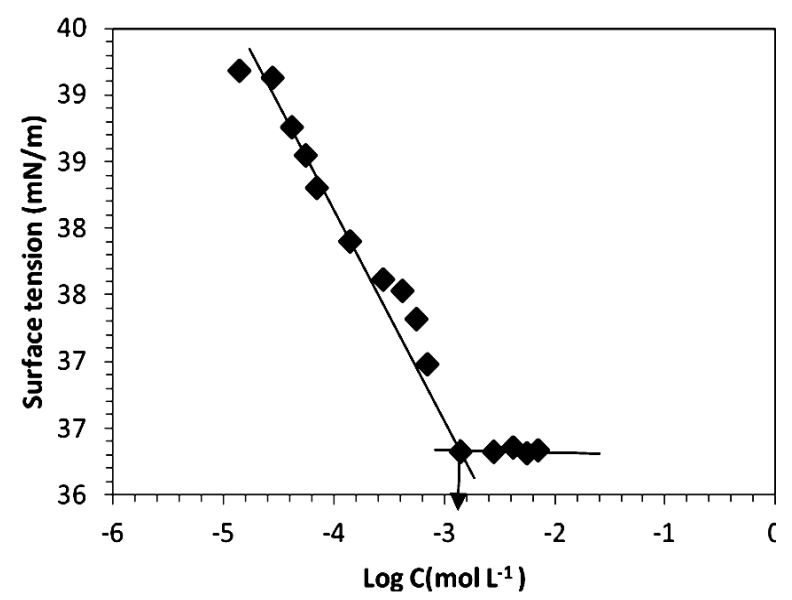

(b)

Figure 3. (a) Surface tension of aqueous solution as a function of [PEG-10 tallow] at $25^{\circ} \mathrm{C}$; (b) Zoom in CMCof the [PEG-10 tallow].

Table 1. CMC values of PEG-10 tallow determined by two methods in different [ $\mathrm{NaCl}]$.

\begin{tabular}{ccc}
\hline \multirow{2}{*}{$\begin{array}{c}\text { NaCl] } \\
\left(\mathbf{m o l} \cdot \mathbf{L}^{-1}\right)\end{array}$} & $\begin{array}{c}\text { Conductivity } \\
\text { method }\end{array}$ & $\begin{array}{c}\text { Surface tension } \\
\text { method }\end{array}$ \\
\cline { 2 - 3 } & 0.0014 & 0.00141 \\
$0.5 \times 10^{-3}$ & 0.0004 & 0.00040 \\
$0.8 \times 10^{-3}$ & 0.0010 & 0.0011 \\
$1 \times 10^{-3}$ & 0.0030 & 0.0032 \\
$2 \times 10^{-3}$ & 0.0036 & 0.0039 \\
\hline
\end{tabular}

causes given a lower CMC value than salt free surfactant solution. However, CMC is getting higherwith the increasing $\mathrm{NaCl}$ concentration $\left(1 \times 10^{-3} \mathrm{~mol} \cdot \mathrm{L}^{-1}\right.$, and $2 \times$ $10^{-3} \mathrm{~mol} \cdot \mathrm{L}^{-1}$ ). Surprisingly, in the higher concentrations of salt, the CMC of PEG-10 tallow was suddenly increased. This can be probably explained by the presence of 10 moles polyoxyethylated groups in the head group of PEG-10 tallow. After a certain concentration of salt, 


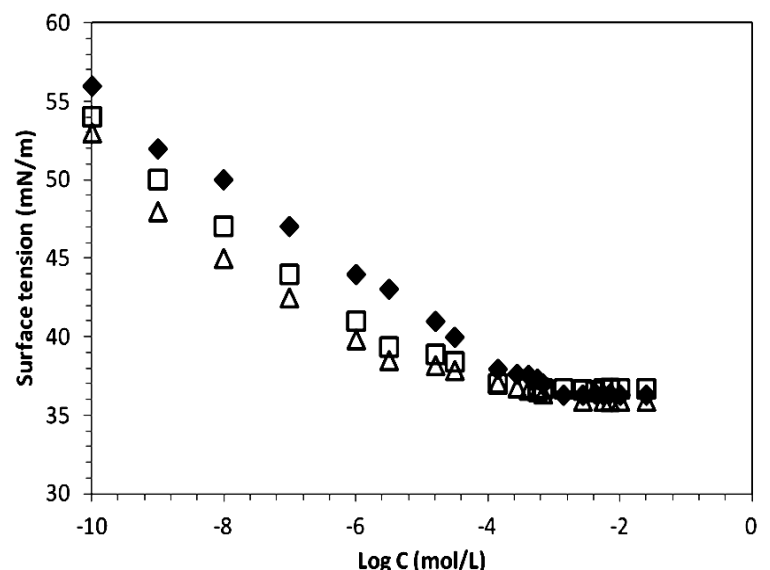

(a)

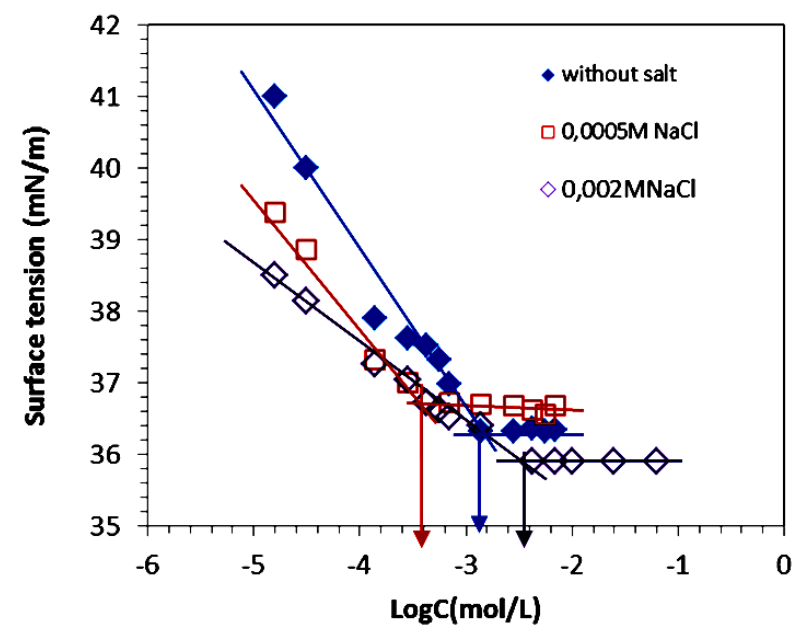

(b)

Figure 4. (a) Plots of surface tension of surfactant in different $[\mathrm{NaCl}]$ at $25^{\circ} \mathrm{C}$ : (४) without salt, ( $\left.\square\right) 0.0005 \mathrm{~mol} \cdot \mathrm{L}^{-1},(\Delta)$ $0.002 \mathrm{~mol} \cdot \mathrm{L}^{-1}$; (b) Zoom in CMC: $(\diamond)$ without salt, ( $\square$ ) $0.0005 \mathrm{~mol} \cdot \mathrm{L}^{-1},(\triangle) 0.002 \mathrm{~mol} \cdot \mathrm{L}^{-1}$.

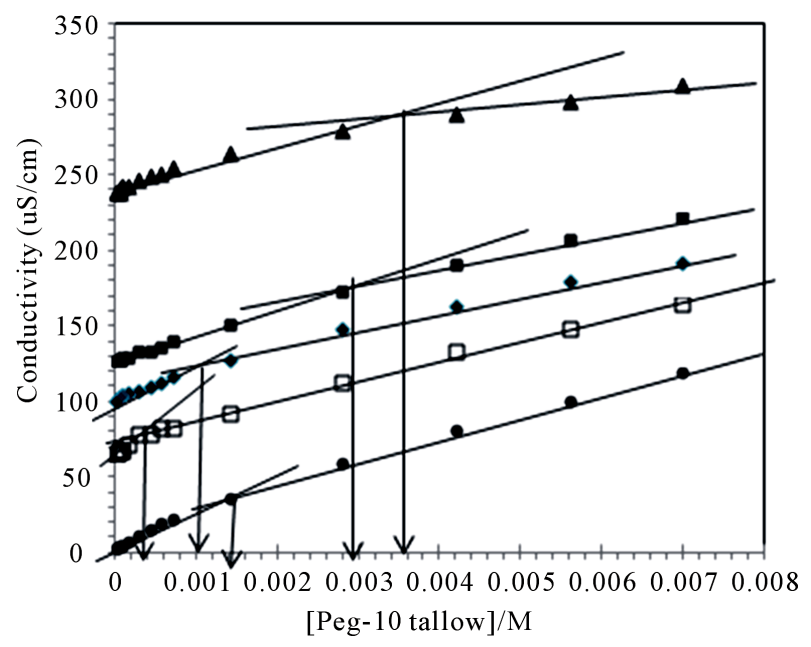

Figure 5. Conductivity plots in different $[\mathrm{NaCl}]$ at $25^{\circ} \mathrm{C}$. (•)

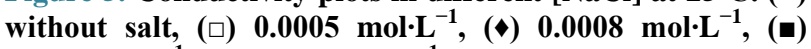
$0.001 \mathrm{~mol} \cdot \mathrm{L}^{-1},(\Delta) 0.002 \mathrm{~mol} \cdot \mathrm{L}^{-1}$. oxygen molecule in PEG chains was increased its interaction with water due to the conformational change of the PEG chains. As previously described in the literature, in POE nonionic surfactants, the CMC was largely affected by the hydration of poly(oxyethylene) chains of the surfactant molecules. In another words, CMC value and size of micelle are increased due to the dehydration of polyoxyethylene chains $[12,13]$.

\subsection{The pH Effect on the CMC of the Cationic Surfactant}

The CMC of PEG-10 tallow was determined with two different methods at various pHs. Surface tension and conductivity measurements were done at different $\mathrm{pH}$ (acidic to alkaline). These values were given in Table 2. The CMC obtained by these methods were found very close each other.

In the present work it was observed that CMC of cationic PEG-10 tallow was increased at acidic $\mathrm{pH}$ as shown in Figure 6. However, CMC of cationic surfactant was affected not very seriously after neutral $\mathrm{pH}$ and it reached to the constant value. Both two methods were supported this finding. The increase CMC of PEG-10 tallow in acid $\mathrm{pH}$ may arise with increase of charge density at the surface of surfactant. In this case the ether lin-

Table 2. The CMC of PEG-10 tallow determined at different pH's.

\begin{tabular}{ccc}
\hline $\mathbf{p H}$ & Surface tension method & Conductance method \\
\hline 3 & 0.0040 & 0.0044 \\
4 & 0.0032 & 0.0038 \\
5 & 0.0025 & 0.0023 \\
6 & 0.0023 & 0.0021 \\
7 & 0.0022 & 0.0020 \\
8 & 0.0022 & 0.0020 \\
9 & 0.0022 & 0.0020 \\
10 & 0.0022 & 0.0020 \\
\hline
\end{tabular}

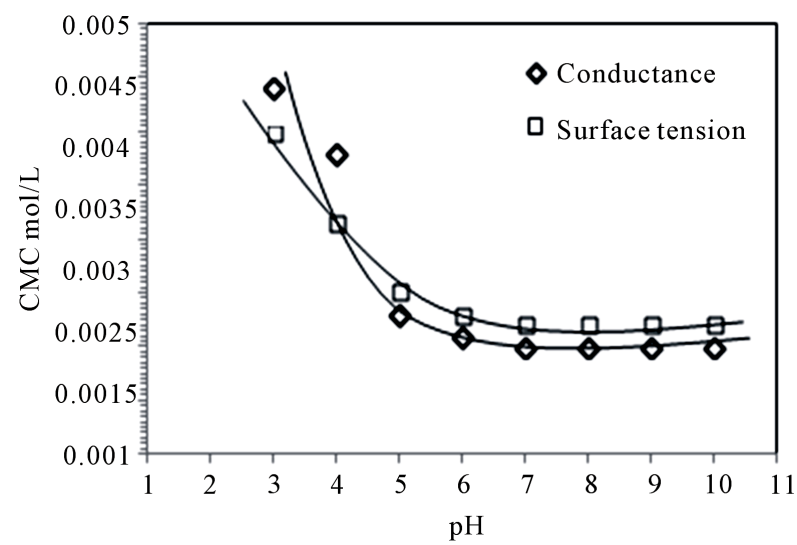

Figure 6. CMC of PEG-10 tallow with two methods determined at various $\mathrm{pH}$ 's. 
kages of poly (oxyethylene) chains can be protonated at acidic pH's yielding more positively charged in head structure of surfactant. These may increase the electrostatic repulsion of the charge heads by increasing the charge density on the surface of the micelle, thus changing the stability of micelle $[13,16,18,19]$. The electrolyte, sodium hydroxide solution, in the present work has no any effect on the changing CMC of PEG-10 tallow. However, hydrogen ions have an effect at quite low concentration. It may be concluded that, CMC is independent of $\mathrm{pH}$ between 6 and 10 and is dependent below 5 .

\section{Conclusion}

Surfactants are generally used in the presence additives in order to improve and understand micellization properties. In this work it was evaluated that the effect of salt and $\mathrm{pH}$ was verifying with two different methods on micellization of PEG-10 tallow. The experimental results were observed: a) CMC of PEG-10 tallow cationic surfactant was increased in high salt $(\mathrm{NaCl})$ concentrations $1 \times 10^{-3} \mathrm{~mol} \cdot \mathrm{L}^{-1}$, and $2 \times 10^{-3} \mathrm{~mol} \cdot \mathrm{L}^{-1}$. Since $10 \mathrm{moles}$ PEG groups in a head group of the molecule were promoted with micellization at higher surfactant concentrations. Whereas in low salt concentrations $0.5 \times 10^{-3} \mathrm{~mol}$. $\mathrm{L}^{-1}$ and $0.8 \times 10^{-3} \mathrm{~mol} \cdot \mathrm{L}^{-1}$, CMC was reduced, favoring the micellization process. b) The $\mathrm{pH}$ was differently affected to CMC of PEG-10 tallow in acidic and alkaline medium. In acidic $\mathrm{pH}$ (from 3 to 5) CMC of cationic surfactant was more obviously increased than that in alkaline medium. $\mathrm{H}^{+}$increased the repulsion of the micelles heads groups and delayed the process of micelle formation. On the other hand, CMC of the PEG-10 tallow in alkaline medium has remained constant but too many smaller changes of CMC were observed than those of individual surfactant solution.

\section{Acknowledgements}

This research was supported by Scientific Research Projects Coordination Center of Yildiz Technical University, Turkey (Project Number: BAPK 92-01-01-02).

\section{REFERENCES}

[1] S. Chavda and P. Bahadur, "Micellization of a Cationic Gemini Surfactant in Aqueous Solutions with Different Alkanols and Alkanediols as Additives: Effect of Nonpolar Chain and Position of Hydroxyl Groups," Journal of Molecular Liquids, Vol. 161, No. 2, 2011, pp. 72-77. http://dx.doi.org/10.1016/j.molliq.2011.04.018

[2] K. T. Naidu and N. P. Prabhu, "Protein-Surfactant Interaction: SDS-Induced Unfolding of Ribonucleases A," The Journal of Physical Chemistry B, Vol. 115, No. 49, 2011, pp. 14760-14767. http://dx.doi.org/10.1021/jp2062496
[3] F. G. S. Klebson, E. L. B. Neto, M. C. P. A. Moura, T. N. D. Dantas and A. A. D. Neto, "Molecular Behavior of Ionic and Nonionic Surfactant in Saline Medium," Colloids and Surfaces A: Physicochemical and Engineering Aspects, Vol. 333, No. 1-3, 2011, pp. 156-162.

[4] S. K. Verma and K. K. Ghosh, "Micellar and Surface Properties of Some Monomeric Surfactants and a Gemini Cationic Surfactant,” Journal of Surfactants and Detergents, Vol. 14, No. 3, 2011, pp. 347-352. http://dx.doi.org/10.1007/s11743-010-1237-0

[5] M. Ikonen, L. Murtomaki and K. Kontturi, "Controlled Complexation of Plasmid DNA with Cationic Polymers: Effect of Surfactant on the Complexation and Stability of the Complexes," Colloids and Surfaces B: Biointerfaces, Vol. 66, No. 1, 2008, pp. 77-83. http://dx.doi.org/10.1016/j.colsurfb.2008.05.012

[6] X. Zhao, Y. Shang, J. Hu, H. Liu and Y. Hu, "Biophysical Characterization of Complexation of DNA Oppositely Charged Gemini Surfactant 12-3-12,” Biophysical Chemistry, Vol. 138, No. 3, 2008, pp. 144-149. http://dx.doi.org/10.1016/j.bpc.2008.09.014

[7] Y. Lin, Y. Zhang, Y. Qiao, J. Huang and B. Xu, "Ligth and Host-Guest Inclusion Mediated Salmon Sperm DNA/ Surfactant Interactions," Journal of Colloid and Interface Science, Vol. 362, No. 2, 2011, pp. 430-438. http://dx.doi.org/10.1016/j.jcis.2011.06.083

[8] S. Bhattachary and S. S. Mandal, "Interaction of Surfactant with DNA. Role of Hydrophobicity and Surface Charge on Intercalation and DNA Melting," Biochimica et Biophysica Acta, Vol. 1323, No. 1, 1997, pp. 29-44. http://dx.doi.org/10.1016/S0005-2736(96)00171-X

[9] R. Liu, J. Yang, C. Sun, X. Wu, L. Li and B. Su, "Study on the Interaction between Nucleic Acids and Cationic Surfactants," Colloids and Surfaces B: Biointerfaces, Vol. 34, No. 1, 2004, pp. 59-63.

http://dx.doi.org/10.1016/j.colsurfb.2003.11.003

[10] Y. He, Y. Shang, S. Shao, H. Liu and Y. Hu, "Micelliation of Cationic Gemini Surfactant and Its Interaction with DNA in Dilute Brine," Journal of Colloid and Interface Science, Vol. 358, No. 2, 2011, pp. 513-520. http://dx.doi.org/10.1016/j.jcis.2011.03.034

[11] X. Zhao, Y. Shang, H. Liu and Y. Hu, "Complexation of DNA with Cationic Gemini Surfactant in Aqueous Solution,” Journal of Colloid and Interface Science, Vol. 314, No. 2, 2007, pp. 478-483. http://dx.doi.org/10.1016/j.jcis.2007.04.059

[12] J. Dey and S. Shrivastava, "Physicochemical Characterization and Self-Assembly Studies on Cationic Surfactants Bearing mPeg Tail,” Langmuir, Vol. 28, No. 50, 2012, pp. 17247-17255. http://dx.doi.org/10.1021/la303210f

[13] J. Jiao, "Polyoxyethylated Nonionic Surfactants and Their Applications in Topical Ocular Drug Delivery," Advanced Drug Delivery Reviews, Vol. 60, No. 15, 2008, pp. 1663-1673. http://dx.doi.org/10.1016/j.addr.2008.09.002

[14] B. Kumar, D. Tikariha and K. K. Ghosh, "Effect of Electrolytes on Micellar and Surface Properties of Some Monomeric Surfactant," Journal of Dispersion Science and Technology, Vol. 33, No. 1-3, 2012, pp. 25-271. 
[15] N. Ataci, I. Correira, I. Arisan and J. C. Marcos, "Selective Precipitation of Plasmid with a Water-Soluble Cationic Surfactant,” Polymers for Advanced Technologies, Vol. 20, No. 3, 2009, pp. 151-155. http://dx.doi.org/10.1002/pat.1245

[16] M. J. Rosen, "Surfactant and Interfacial Phenomena," John \& Wiley, New York, 1978.

[17] X. Zhou and J. Hao, "Solubility of $\mathrm{NaBr}, \mathrm{NaCl}$ and $\mathrm{KBr}$ in Surfactant Aqueous Solutions," Journal of Chemical \& Engineering Data, Vol. 56, No. 4, 2011, pp. 951-955. http://dx.doi.org/10.1021/je100905g
[18] A. Rahman and C. W. Brown, "Effect of pH on the Critical Micelle Concentration of Sodium Dodecyl Sulphate," Journal of Applied Polymer Science, Vol. 28, No. 4, 1983, pp. 1331-1334. http://dx.doi.org/10.1002/app.1983.070280407

[19] T. Zhou, H. Yang, X. Xu, X. Wang, J. Wang and G. Dong, "Synthesis Surface and Aggregation Properties of Nonionic Poly(Ethylene Oxide) Gemini Surfactants," Colloids and Surfaces A, Vol. 317, No. 1, 2008, pp. 339343. http://dx.doi.org/10.1016/j.colsurfa.2007.11.008 